\title{
Economics of Different Horticultural Crops under Arecanut Based Multistoreyed Cropping System in West Bengal Condition
}

\author{
G. Chandrashekhar ${ }^{1^{*}}$ and H. Bhattacharjee ${ }^{2}$ \\ ${ }^{1}$ Department of Spices and Plantation Crops, Faculty of Horticulture, Bidhan Chandra Krishi \\ Viswavidyalaya, Mohanpur, Nadia, 741252, West Bengal, India \\ ${ }^{2}$ Department of Plantation Crops and Processing, Uttar Banga Krishi Viswavidyalaya \\ Pundibari, Coochbehar - 736165, West Bengal, India \\ *Corresponding author
}

\begin{abstract}
A B S T R A C T
Keywords

Arecanut, Cropping systems, Intercrops, Mixed cropping, B: C ratio

Article Info

Accepted:

23 March 2018

Available Online:

10 April 2018

Multi-storey cropping is practiced for growing two or more crops in the inter spaces during main crop growing season and which include both inter and mixed cropping. Mixed cropping in arecanut plantation has promoted more growth and yield of main crop of arecanut as indicated by increased number of leaves (fronds) and increased yield per palm compared to sole crop. Yield and income of five representative samples of arecanut (main crop) and the intercrops from all the seven models were observed. Maximum mean yield of arecanut was observed to be in var. Mohitnagar $(1.590 \mathrm{~kg} / \mathrm{plant})$, while minimum was in var. Mangala (1.348kg/plant). Maximum income and B:C ratio of Rs. 36,919.95 and 3.68:1 respectively were observed in Model-III, while minimum income Rs. 15,637.15 was in Model-I. Minimum B: C ratio of 1.13:1 was observed to be in Model-VI. It can be concluded that, Model - III (Arecanut + Banana + Turmeric) was the best remunerative one and the farmers can adopt this model in this region as areca nut based multi-storey cropping system for more income per unit area.
\end{abstract}

\section{Introduction}

Arecanut palm (Areca catechu L.), is important plantation crop in whole of South East Asia including India. Horticulture crops particularly fruit and plantation crops have self-sustainable system where solar energy can be harvested at different heights, soil resources are used efficiently and can increase cropping intensities. This modern approach is boon to small and marginal farmers who are major stakeholders in Indian Agriculture/ Horticulture system in present and future days.
Due to various constraints, many arecanut growers are not able to adopt the multispecies cropping system to the desired level. Arecanut as a sole crop does not fully utilize the natural resources such as soil, space, and light.

The compact nature of arecanut crown, raised well above the ground (10 to $15 \mathrm{~m}$ ), allows more sunlight to pass down to ground and maintain high humidity which in turn favors excellent growth of shade loving crops. So, multiple cropping in arecanut was the ability to provide substantial increase of diversified 
crops and income per unit area through better utilization of resources like land, space, light and nutrients.

In West Bengal, arecanut cultivation is mainly restricted to North Bengal, but due to fluctuation of price, people are losing interest in arecanut cultivation. Arecanut is a perennial crop and it can produce fruits up to 40 to 50 years. Intercropping in plantation crop garden helps to meet the food requirement, besides increasing the net returns per unit area (Nair and Verghese, 1976). Areca nut based cropping systems have been developed for different places and net returns from the garden have been increasing many fold.

\section{Materials and Methods}

The experiment was undertaken at Horticultural Instructional Farm, UBKV. Seven different models (Table 1): Model-I with Arecanut as monocrop; Model-II with Arecanut + Turmeric, Model-III with Arecanut + Banana + Turmeric; Model-IV with Arecanut + Cow pea + Tomato; Model-V with Arecanut + Chilli + Spinach; Model-VI with Arecanut + Banana + Okra + Brinjal and Model-VII with Arecanut + Chilli + Coriander were established during 2014-15 (Fig. 1). The experimental site is of six years old.

Spacing followed for arecanut and banana and was $2.7 \mathrm{~m} \times 2.7 \mathrm{~m}$ and $5.4 \mathrm{~m} \times 5.4 \mathrm{~m}$, respectively and remained same under all treatment combinations. The package of practices recommended for the young arecanut was accordingly followed (Bhat and Leela, 1968). Crops were supplied with recommended fertilizers and other operations were carried out as and when required. The yield, cost of production and $\mathrm{B}$ : $\mathrm{C}$ ratio of different intercrops were estimated following simple statistical programmes taking into consideration of the prevailing Pundibari region market price.

\section{Results and Discussion}

The present investigation, seven plots of arecanut palm planted during 2003-'04 were selected. Various crops grown with their duration of cultivation have been presented in Table 1. In total, there were eight existing plots of arecanut in the block, out of which, for the present experiment seven plots, three plots with Mohitnagar and one each with Mangala, Sreemangala, Sumangala and Kahikuchi were selected for establishment of seven various models. In the first model (Model-I), had only arecanut as monocrop, In second model (Model-II), Turmeric was interplanted in the beds prepared in the interspaces of arecanut (main crop), banana suckers were planted in rows and turmeric in the beds between the rows of arecanut in the third model (Model-III). Sit et al., (2006) studied the feasibility of growing 25 vegetables intercropping in 36 years old arecanut garden under sub-Himalayan Terai region of West Bengal.

Girijadevi and Muralidharan Nair (2003) also reported banana and turmeric as intercrops in coconut garden. In the fourth model (ModelIV), cow pea and tomato were grown in the inter spaces; in the fifth model (Model-V) chilli and spinach were interplanted in beds between the rows of arecanut. In the sixth model (Model-VI), banana in the same rows of arecanut (main crop) along with okra followed by brinjal were grown in the beds prepared in between arecanut, Girijadevi and Muralidharan Nair (2003) reported 7 cropping systems in coconut garden with banana, vegetable, cow pea, ginger and other crops in Kerala. Ray et al., (2007) reported seven vegetable crops including tomato and brinjal and three flowering crops in a three year old arecanut (var. Mohitnagar) at CPCRI, RC, Kahikuchi, Assam. In seventh model (ModelVII), chilli followed by coriander was grown (Nair et al., 2000). 
Table.1 Details of various crops interplanted in existing arecanut based multistorey cropping models

\begin{tabular}{|c|c|c|c|c|}
\hline Model & \multicolumn{4}{|c|}{ Main crop and inter-crops } \\
\hline Model-I & Arecanut & -- & -- & -- \\
\hline Model-II & Arecanut & $\begin{array}{c}\text { Turmeric } \\
\text { (May.'14 to Feb.'15) }\end{array}$ & -- & -- \\
\hline Model-III & Arecanut & $\begin{array}{c}\text { Banana } \\
\text { (May.'14 to till date) }\end{array}$ & $\begin{array}{c}\text { Turmeric } \\
\text { (May,'14 to Feb.'15) }\end{array}$ & -- \\
\hline Model-IV & Arecanut & $\begin{array}{c}\text { Cow pea } \\
\text { (Jun.'14 to Sept.'14) }\end{array}$ & $\begin{array}{c}\text { Tomato } \\
\text { (Oct.'14 to Jan.'15) }\end{array}$ & -- \\
\hline Model-V & Arecanut & $\begin{array}{c}\text { Chilli } \\
\text { (Jun.'14 to Sept.'14) }\end{array}$ & $\begin{array}{c}\text { Spinach } \\
\text { (Oct.'14 to Dec.'14) }\end{array}$ & -- \\
\hline Model-VI & Arecanut & $\begin{array}{c}\text { Banana } \\
\text { (May.'14 to till date) }\end{array}$ & $\begin{array}{c}\text { Okra } \\
\text { (Jun.'14 to Sep.'14) }\end{array}$ & $\begin{array}{c}\text { Brinjal } \\
\text { (Oct.'14 to Jan.'15) }\end{array}$ \\
\hline Model-VII & Arecanut & $\begin{array}{c}\text { Chilli } \\
\text { (Jun.'14 to Sept.'14) }\end{array}$ & $\begin{array}{c}\text { Coriander } \\
\text { (Oct.'14 to Jan.'15) }\end{array}$ & -- \\
\hline
\end{tabular}

Table.2 Observations on economics of main crop (arecanut) and component crops

\begin{tabular}{|c|c|c|c|c|c|c|c|c|c|c|c|c|}
\hline \multirow[b]{2}{*}{ Model } & \multicolumn{8}{|c|}{ Cost of cultivation (Per plot of $324 \mathrm{~m} 2$ ) } & \multicolumn{4}{|c|}{ Per ha } \\
\hline & $\begin{array}{l}\text { Land } \\
\text { Preparatio } \\
\text { n, seed } \\
\text { material, } \\
\text { planting }\end{array}$ & $\begin{array}{l}\text { Inter- } \\
\text { cultural } \\
\text { operation } \\
\mathrm{s}\end{array}$ & $\begin{array}{l}\text { Agro- } \\
\text { chemica } \\
\text { ls }\end{array}$ & $\begin{array}{l}\text { Harvestin } \\
\mathrm{g} \text { and } \\
\text { post- } \\
\text { harvest } \\
\text { operations }\end{array}$ & $\begin{array}{l}\text { Gross } \\
\text { expenditur } \\
\text { e }\end{array}$ & $\begin{array}{l}\text { Gross } \\
\text { return }\end{array}$ & $\begin{array}{l}\text { Net } \\
\text { return }\end{array}$ & $\begin{array}{l}\mathrm{B}: \mathrm{C} \\
\text { ratio }\end{array}$ & $\begin{array}{l}\text { Gross } \\
\text { expenditur } \\
\text { e }\end{array}$ & $\begin{array}{l}\text { Gross } \\
\text { Return }\end{array}$ & $\begin{array}{l}\text { Net } \\
\text { return }\end{array}$ & $\begin{array}{l}\text { B:C } \\
\text { Rati } \\
\text { o }\end{array}$ \\
\hline Model-I & -- & 2,300 & 258 & 1,074 & 3,632 & 15,523 & 11,891 & $3.3: 1$ & $1,12,099$ & $4,79,105$ & $3,67,006$ & $3.3: 1$ \\
\hline Model-II & 860 & 3,000 & 521 & 1,274 & 5,655 & 25,751 & 20,096 & 3.6:1 & $1,74,537$ & $7,94,628$ & $6,20,091$ & 3.6:1 \\
\hline Model-III & 1,604 & 3,800 & 1,008 & 1,474 & 7,886 & 33,522 & 25,636 & $3.3: 1$ & $2,43,395$ & $10,34,435$ & $7,91,040$ & 3.3:1 \\
\hline Model-IV & 1,454 & 3,400 & 476 & 2,274 & 7,604 & 26,075 & 18,471 & $2.4: 1$ & $2,34,691$ & $8,04,614$ & $5,69,923$ & $2.4: 1$ \\
\hline Model-V & 1,668 & 3,400 & 488 & 2,274 & 7,830 & 26,637 & 18,807 & $2.4: 1$ & $2,41,667$ & $8,21,948$ & $5,80,281$ & $2.4: 1$ \\
\hline Model-VI & 2,818 & 4,200 & 977 & 2,874 & 10,869 & $27,234^{*}$ & 16,365 & $1.5: 1$ & $3,35,463$ & $8,40,555^{*}$ & $5,05,092$ & $1.5: 1$ \\
\hline Model-VII & 1,650 & 3,400 & 496 & 2,274 & 7,820 & 28,843 & 21,023 & 2.7:1 & $2,41,358$ & $8,90,070$ & $6,48,712$ & 2.7:1 \\
\hline
\end{tabular}


Fig.1 Photographs of various models
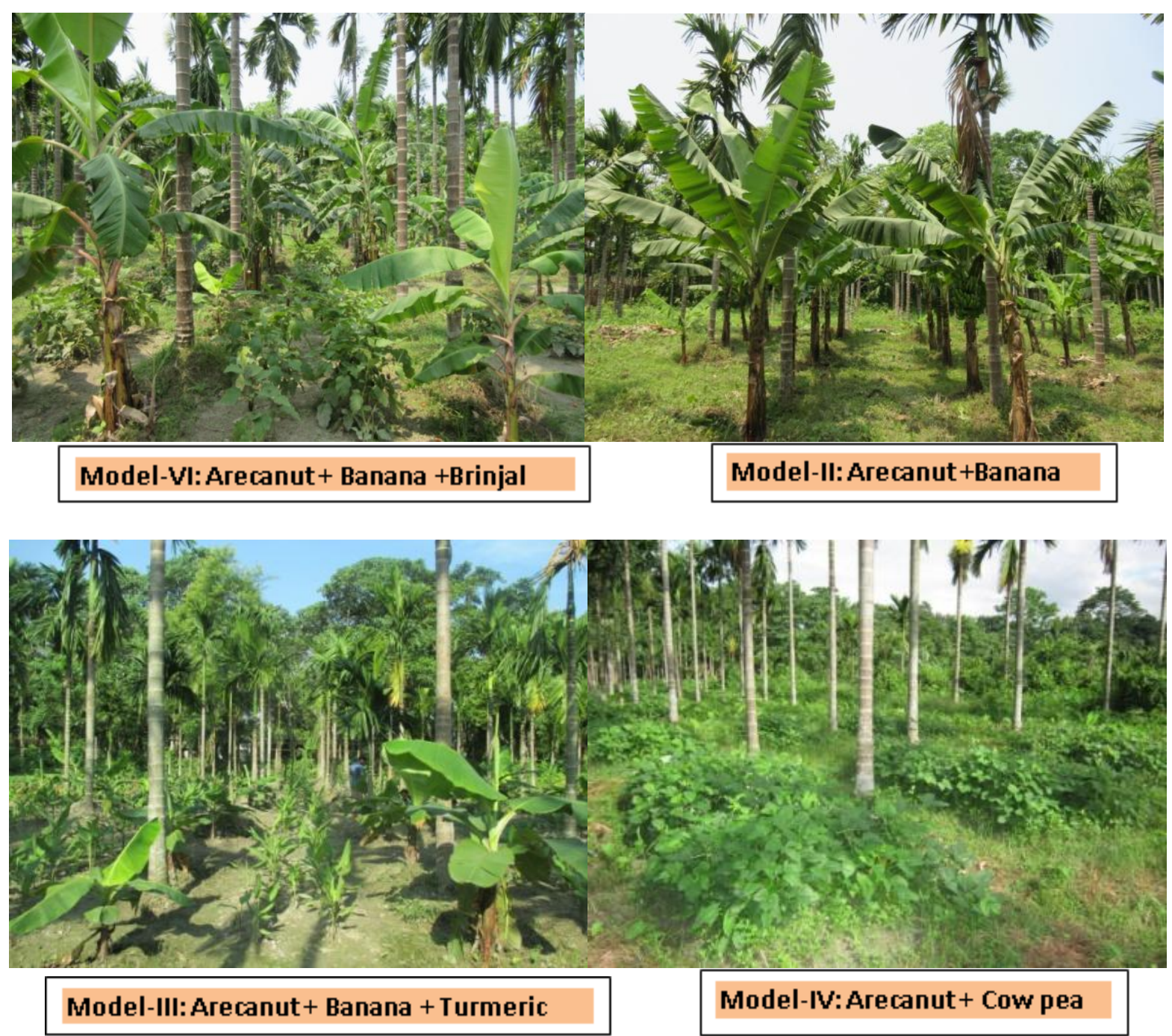

Reported cultivation of perennial intercrops in arecanut garden permits only a single return in a year whereas cultivation of vegetables as intercrops might help to get frequent returns (Nair et al., 2000). Roy and Hore (2011) reported bio-organic inputs on growth, yield and economics of turmeric grown as intercrop in arecanut plantation at Horticulture Research Station, Mondouri, BCKV, West Bengal.

The economic analysis involving cost of cultivation, gross return, net return, and $\mathrm{B}$ : $\mathrm{C}$ Ratio for finding out the most remunerative model has been presented in Table 2. It is clear from the table (Table 2) that in Model-I arecanut was grown as monocrop an income of Rs, 15,637.15 was obtained. For Model -IV arecanut, cow pea and tomato were grown. Total cost of cultivation (Table 2) was Rs. 7,604 for harvesting and related operations net return of Rs.26,986.38 could be obtained from that model.

Gross income from Model-V growing chilli, along with arecanut as main crop was Rs. 27456.82 incurring a gross expenditure of Rs.7,830 (Table 2). In Model-VI, arecanut, banana, okra and brinjal were grown. This model had maximum cost of cultivation of Rs 
10,869 , as it involved more number of labours for land preparation, intercultural operations and harvesting (Table 2). Net return from this model was observed to be Rs.23173.14. Roy and Hore (2011) also reported maximum cost of cultivation of Rs. 1,09,744 per ha, gross return of Rs 27234.

Benefit cost ratio, as revealed from Table 2, was the highest (3.68:1) in Model -III where, banana and turmeric were grown as intercrops with arecanut. While minimum (1.13:1) in case of Model-VI where banana, okra and brinjal were grown along with arecanut as main crop. Sit et al., (2006) reported that the $\mathrm{B}$ : $\mathrm{C}$ ratio ranged between 0.37 in case of bitter gourd to 3.44 in case of cabbage as intercrop with arecanut. Model- II with turmeric as intercrops with arecanut and Model-I with arecanut as monocrop had the Benefit: cost ratios of 3.63:1 and 3.31:1; while Model-VII, the benefit cost ratio was observed to be 2.19:1. Girijadevi and Muralidharan Nair (2003) reported various B: C ratios- 1.59 with banana, 2.28 banana + ginger, 1.89 banana+ ginger +vegetable cowpea, 1.56 with banana+ turmeric and 1.64 with only banana in arecanut garden. In both the Models IV and V, the benefit cost ratio was observed to be 2.55:1 and 2.51:1, respectively. Sit et al., (2006) also observed B: C ratio 1.39 with spinach as intercrop in 36 years old arecanut garden at Mohitnagar, West Bengal. Ray et al., (2007) reported B: C ratio of 2.57 with tomato and 5.05 with brinjal as intercrops. Nath et al., (2002) revealed that out of three models studied, the model with coconut + black pepper + banana + Assam lemon + pine apple + ginger was the most remunerative one, recording the highest net return of Rs. 63,488/ha, followed by coconut + betel vine + banana + Assam lemon + turmeric + colocasia with Rs. 31, 406/ha, while the minimum net profit of Rs. $16,074 /$ ha was recorded in the coconut monocropping system. The mixed cropping systems arecanut + cardamom + pepper and arecanut + pepper, respectively recorded $141.30 \%$ and $119.69 \%$ more profits over and above the profit from sole crop (Girish et al., 2003). Bari and Rahim (2012) recorded the highest benefit cost ratio (BCR) from coconut + guava based MAF. Shahapurmath et al., (2003) also obtained all the mixed cropping systems studied were found to be economically better, with a net profit per hectare ranging from Rs. 3,52,858 in arecanut + cardamom + pepper to Rs. 1,69,539 in arecanut + banana, compared to sole cropping of arecanut (Rs. 1,46,227/ha). Sit et al., (2006) B: C ratio of all the crops ranged between 0.37 (bitter gourd) to 3.44 (cabbage), however, all the vegetables tested were found to be profitable.

It is clear from Table 2 that maximum profit of Rs.36,919.95 could be earned from Model -III where banana along the rows of arecanut and turmeric in the beds in the interspaces were grown. Minimum profit Rs.15,637.15 could be earned incurring minimum expenditure of Rs. 3,632 per plot of $324 \mathrm{~m}^{2}$ growing arecanut as monocrop. Girijadevi and Muralidharn Nair (2003) also found benefit: cost ratio was reported to be the highest in banana + ginger + vegetable cow pea in coconut based intercropping system at Kerala Agriculture University. Kakaty et al., (2002) opined that the combinations of banana + pineapple + arecanut and pineapple + cowpea + French bean + arecanut were effective in increasing yield, gross return and net profit along with higher benefit: cost ratio in both cases of bearing and pre-bearing areca-based multistored cropping system in Assam.

The present investigation for only one year, it could be concluded that incorporation of intercrops as multistoreyed cropping in arecanut garden besides generating more income from those crops, yield and return 
from arecanut also increased. So, the farmers in this region, like in South India can very well cultivate various inter-crops as multistoreyed cropping system for more yield of not only arecanut but also getting yield and subsequently more income per unit area, reducing the risk of long gestation period and fluctuating prices of growing arecanut as monocrop.

\section{References}

Bhat, K. S. and Leela, M. 1968. Cultural requirement of arecanut. Indian Farming 18 (4): 8-9.

Girijadevi, L. and Nair, Muraleedharan, V.2003. Economics of coconut based intercropping systems. Journal of Planation. Crops, 31: 45-47.

Girish, B., Shahapurmath, H., Shivanna and Girisha, H. V. 2003. Economic analysis of arecanut based agroforesty models. Karnataka J. Agric. Sci. 16(2):265-270.

Kakaty, B. M., Chakrabarty, B. K. and Thakur, A. C. 2002. Multistoreyed cropping in bearing and pre-bearing arecanut plantations in Assam. Journal of Plantation Crops 30(2): 33-38.

Nair, A. K., Nair, S. A., Dubey, R. P., Ravisankar, N. and Pramanik, S. C. 2000. Evaluation of cucurbitaceous vegetables as intercrops in coconut plantations of Andamans. Indian Journal of Agricultural Sciences 70(4): 241-42.

Nair, P. K. R. and Verghese, P. T. 1976. Crop diversification in coconut plantation. Indian Farming 24(11): 17-21.
Nath, J. C. 2002. Prospects of coconut based high density multistoreyed cropping in Assam. Indian Coconut Journal 33(3): $10-11$.

Ray, A. K., Borah, A. S., Maheswarappa, H. P. and Acharya, G. C. 2007. Economics of intercropping vegetables and flowering crops in pre-bearing arecanut garden under Assam condition. Journal Plantation Crops 35(2): 84-87

Roy, S. S. and Hore, J. K. 2011a. Effect of different bio-organic inputs on growth, yield and economics of turmeric grown as intercrop in arecanut plantation. Indian Journal of Horticulture 68(3).

Roy, S. S. and Hore, J. K. 2011b. Effect of organic manures and microbial inoculants on yield, root colonization and total bacterial population in turmeric (Curcuma Longa L.) intercropped in arecanut (Areca catechu L.) garden. Journal of Spices and Aromatic Crops 20(2).

Shahapurmath G B., Shivanna, H. and Girisha, H. V. 2003a. Performance of arecanut based mixed cropping systems. Karnataka Journal of Agricultural Sciences 16(2): 254-59.

Sit, A. K., Acharya, G. C., Chenniah, K. C. And Ghosh, A. 2006. Feasibility of vegetable intercropping in arecanut garden under sub Himalayan Terai region of West Bengal. Journal of Plantation Crops 34(3): 361-63.

\section{How to cite this article:}

Chandrashekhar, G. and Bhattacharjee, H. 2018. Economics of Different Horticultural Crops under Arecanut Based Multistoreyed Cropping System in West Bengal Condition. Int.J.Curr.Microbiol.App.Sci. 7(04): 2756-2761. doi: https://doi.org/10.20546/ijcmas.2018.704.314 